Table 1. Asparagus yield by size for three cutting heights $(13,18$, and $23 \mathrm{~cm})$ for $1989-91$.

\section{Yield and Grade of Asparagus Harvested at Three Spear Heights}

\author{
Bill B. Dean \\ Irrigated Agriculture Research and Extension Center, Washington State \\ University-Prosser, Prosser, WA 99350-9687
}

Additional index words. Asparagus officinalis

Although reports have been published regarding the merits of field snapping vs. cutting asparagus (Asparagus officinalis L.) (Barrons, 1945; Carolus, 1949), the amount of trim loss obtained from various cutting techniques (Barrington and Clore, 1964), and the effect of extended cutting seasons on yield (Jones, 1932), I found no reports on the effect of cutting height on yield.

The purpose of this project was to determine if marketable yield or grade is affected when spears are cut at various heights.

A uniform plot of 'Glenn Smith Mary Washington' asparagus planted as transplants in 1987 was used for this study. The experiment was located at the Roza Unit, Irrigated Agriculture Research and Extension Center, Presser, Wash. The soil is a Warden silt loam with a history of pasture or cover crop previous to being planted to asparagus. Soil fertility was maintained by adding $21 \mathrm{~kg} \mathrm{~N} / \mathrm{ha}$ annually to meet estimated crop demands. Water was applied by an overhead sprinkler irrigation system as needed. Weeds and insect pests were controlled using standard cultural practices recommended by Thornton et al. (1982). The plots were $10 \times 3 \mathrm{~m}$ and consisted of two

Received for publication 6 Apr. 1992. Accepted for publication 26 Feb. 1993. Hort/LA paper no. 92-07, project no. 0766, College of Agriculture and Home Economics Research Center, Washington State Univ., Pullman. The cost of publishing this paper was defrayed in part by the payment of page charges. Under postal regulations, this paper therefore must be hereby marked advertisement solely to indicate this fact. rows of plants spaced $0.4 \mathrm{~m}$ between plants and $1.5 \mathrm{~m}$ between rows. There were five replications in a randomized complete-block design.

Harvest began 20, 13, and 11 Apr. 1989, 1990, and 1991, respectively. Plots were harvested daily for 22, 49, and 63 days in 1989 , 1990, and 1991, respectively. Spears were cut just below the soil surface to 13,18 , and $23 \mathrm{~cm}$ high. Spears were graded twice per week into base diameter sizes of small $(0.6-0.95 \mathrm{~cm})$, medium $(1.0-1.25 \mathrm{~cm})$, large $(1.26-1.59 \mathrm{~cm})$, jumbo $(>1.6 \mathrm{~cm})$, and culls. Statistical analyses were performed using Statistical Analysis System (SAS) analysis of variance software (SAS, Cary, N.C.).

Total spear yield from these plots increased with each increase in cutting height in all cases, except for the yield of 18 - and $23-\mathrm{cm}-$ high spears in 1990. Spear yield in each size class increased in all cases, except for the yield of small spears in 1989, although the increases were not always significantly different. Spear weight in the cull class also increased in all cases, except for the weight of 18 -cm-high spears in 1991, although the treatments were not always significantly different.

The yield data, combined for years, showed significant effects of all treatments (Table 1). Yields of small and medium spears were significantly lower when cut at $13 \mathrm{~cm}$ rather than 18 or $23 \mathrm{~cm}$. Yields of large and jumbo spears increased significantly with each increase in cutting height, as did total yield.

The differences in yield between years were significant; however, the number of days of cutting for each year was also different and,

\begin{tabular}{|c|c|c|c|c|}
\hline \multirow[b]{3}{*}{ Size } & \multirow{2}{*}{\multicolumn{3}{|c|}{$\begin{array}{c}\text { Yield }\left(\mathrm{kg} \cdot \mathrm{ha}^{-1}\right) \\
\text { Height when cut }(\mathrm{cm})\end{array}$}} & \multirow[b]{3}{*}{$\mathrm{LSD}_{005^{\prime}}$} \\
\hline & & & & \\
\hline & 13 & 18 & 23 & \\
\hline Small & 113 & 170 & 171 & 24 \\
\hline Medium & 276 & 415 & 434 & 61 \\
\hline Large & 724 & 877 & 1130 & 134 \\
\hline Jumbo & 261 & 463 & 595 & 81 \\
\hline Cull & 179 & 325 & 551 & 61 \\
\hline Total & 1553 & 2250 & 2881 & 297 \\
\hline
\end{tabular}

${ }^{2} P>\mathrm{F}$; significant at $P \leq 0.01$.

therefore, no conclusions can be made from these differences. If the total yield per day is calculated for each treatment, the highest average yield $\left(71 \mathrm{~kg} \cdot \mathrm{ha}^{-1}\right)$ for all treatments per day was obtained in 1989; yield per day was 43 and $46 \mathrm{~kg} \cdot \mathrm{ha}^{-1}$ in 1990 and 1991, respectively. The high yield in 1989 likely resulted from its being the first cutting of a new planting. Because the treatments gave consistent results each year (increased total yield with cutting height), the carbohydrate supply or other factors that control total yield did not seem to be affected by cutting height. Therefore, harvesting taller spears under the conditions of this experiment would result in higher grower returns, because of a higher proportion of large and jumbo spears, without adversely affecting long-term yields.

\section{Literature Cited}

Barrons, K.C. 1945. The field snapping method of harvesting asparagus. Michigan Agr. Expt. Sta. Quarterly Bul. 28:111-114.

Carolus, R.L. 1949. Yield and quality of asparagus harvested by the field snapping method. Michigan Agr. Expt. Sta. Quarterly Bul. 31:370-377.

Barrington, A.H. and W.J. Clore. 1964. Yield studies from harvesting for processing requirements, fresh market requirements and other grade standards. Washington Asparagus School Presentation, 15 Feb. 1964.

Jones, H.A. 1932. Effect of extending the cutting season on the yield of asparagus. Univ. of California College of Agr. Expt. Sta. Bul. 353.

Thornton, R., W. Ford, R. Dyck, W. Cone, R. Parker, and O. Maloy. 1982. Washington asparagus production guide. Washington State Univ. College of Agr. Ext. Bul. EB0997. 